\title{
A qualitative comparative analysis of collaborative governance structures as applied in urban gardens
}

\author{
Astrid Molenveld, William Voorberg , Arwin Van Buuren \& Liselotte Hagen
}

To cite this article: Astrid Molenveld, William Voorberg , Arwin Van Buuren \& Liselotte Hagen (2021): A qualitative comparative analysis of collaborative governance structures as applied in urban gardens, Public Management Review, DOI: 10.1080/14719037.2021.1879912

To link to this article: https://doi.org/10.1080/14719037.2021.1879912

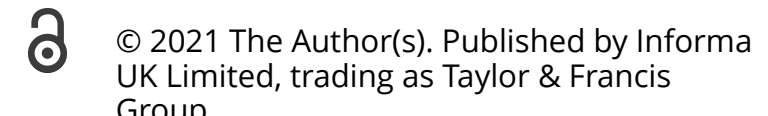
Group.

Published online: 18 Feb 2021.

Submit your article to this journal ¿

Џ Article views: 291

Q View related articles $\square$

View Crossmark data ¿ 


\title{
A qualitative comparative analysis of collaborative governance structures as applied in urban gardens
}

\author{
Astrid Molenvelda, William Voorberga ${ }^{a}$, Arwin Van Buuren ${ }^{a}$ and Liselotte Hagen ${ }^{b}$ \\ aDepartment of Public Administration and Sociology, Erasmus Universiteit Rotterdam, Netherlands;

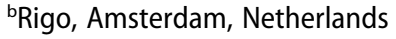

\begin{abstract}
Many public issues require collaboration between governments, private actors, NGOs, civic organizations, and individual organizations. Initiating such a collaboration is challenging, but sustaining such a partnership can be even more difficult. This paper aims to explore what types of collaborative governance structures (CGSs) are found in urban gardens that have continued to exist over the years and that have been discontinued. In order to do this, we analysed 14 urban gardens in the Netherlands as striking examples of CGSs. By applying Fuzzy-set Qualitative Comparative Analysis (FsQCA), we were able to unravel plausible explanations for gardens that (did not) stand the test of time. The analysis shows that financial independence, strong institutionalization, and having a small core group of volunteers is the most important configuration for the durability of an urban garden. Even though some gardens were meant to be temporary, this structure made them durable. Two urban gardens ${ }^{-}$envisioned to be temporal ${ }^{-}$did not develop an institutional design or financial independence, which led to their discontinuation.
\end{abstract}

KEYWORDS Collaborative governance structure; fuzzy-set qualitative comparative analysis (FsQCA); urban gardens

\section{Introduction}

Recently, the scholarly literature has shifted to a new focus on collaborative arr angements in urban governance (Edelenbos, van Meerkerk, and Schenk 2016; Rosol 2010, p. 549; Van Meerkerk, Kleinhans, and Molenveld 2018). Frantzeskaki $(2019,104)$ described them as a way for residents to reclaim the public space and self-govern the domain, which is a move away from a nanny state providing such services (Rosol 2010). Collaborative governance is heralded as a meaningful concept to understand the complexity of such collaborative structures (Ansell and Gash 2007).

This paper examines urban gardens from the perspective of collaborative governance structures (CGSs). This concept can be defined as public policy or serviceoriented, cross-organizational systems involving a range of autonomous organizations or individuals representing different interests and/or jurisdictions (Emerson and Gerlak 2014, 769). 
To date, research on CGSs has predominantly focused on the barriers and success factors present in government-initiated collaborative structures and the possibilities for multiple actors to join CGSs (Erickson et al. 2003; Newman et al. 2004; Voets, Verhoest, and Molenveld 2015). Looking at other bodies of literature, we find more conditions and key factors that determine the quality of cross-sector collaboration (Bryson, Crosby, and Middleton Stone 2006), the effectiveness of governance networks (Sørensen and Torfing 2009), or their limitations (Agranoff and McGuire 2001). This research adds to these bodies of literature an empirical explanation why certain factors contribute to the endurance of such a collaboration and (more importantly) how combinations of these factors explain collaboration. In doing so, this research adds a more nuanced perspective on the effect of certain factors on a collaborative outcome.

Ansell and Gash (2007), however, advocated for a contingency approach to collaborative governance structures and urged researchers to delve into the contextual conditions that might facilitate or discourage a structure. In other words, research has yet to show how combinations of conditions affect the durability of CGSs (Emerson, Nabatchi, and Balogh 2012, 22). To this end, we compare 14 similar CGSs within urban spatial planning. The cases involve urban gardens as examples of CGS. These gardens entail a partnership between citizens, civic organizations, and public authorities concerned with the initiation and maintenance of the garden. In doing so, this research adds a nuanced perspective on the effect of certain factors on a collaborative outcome. By applying a fuzzy-set Qualitative Comparative Analysis (FsQCA) (Ragin 2008a), we are able to identify what conditions are necessary and sufficient in urban gardens that show to be durable over time. This paper intends to answer the following research question: What kind of collaborative governance structures (CGSs) in urban gardens are durable over time, and what conditions explain their durability?

This research adds to the bodies of literature on collaborative governance (1) an empirical explanation about what individual conditions matter when looking to CGSs and (2) how combinations of these conditions explain the durability of CGSs. Firstly, our goal is to identify conditions that might explain the durability of CGSs. Therefore, the next section elaborates on the concept of collaborative governance and the notion of CGS. We describe the assumed critical factors and 'translate' them into factors for analysis. In order to enhance our understanding, we study the various configurations of conditions that can explain the durability of CGSs and how they interact with each other. In the subsequent section, we provide information on our case selection, explain why these cases are illustrative for CGSs, and elaborate on the method. In the section after that, the results of our study are shown. Next, we interpret these findings and discuss their implications for our understanding of CGSs. We conclude the paper by acknowledging the limitations of this study and suggesting directions for future research.

\section{What conditions collaborative governance structures?}

Both Ansell and Gash (2007) and Emerson, Nabatchi, and Balogh (2012) published widely cited literature reviews and described a structure as the building block for a steady collaborative governance process over time (Emerson, Nabatchi, and Balogh $2012,5)$. One of the key features of CGS is the inclusion and diverse roles of non-state actors (Pahl-Wostl 2009, 357). First, the word governance encompasses coordination 
and steering processes which establish formal and informal institutions that guide behaviour (Scharpf 1997; Stoker 1998). What makes a governance arena a structure is the relative strength of its formal and informal procedures and institutions, respectively (Pahl-Wostl 2009, 356). CGSs develop intentional institutional arrangements and procedural norms that foster collaboration (Emerson and Gerlak 2014). Thereby, the formal character of such collaboration is strengthened.

Both Emerson, Nabatchi, and Balogh (2012) and Ansell and Gash (2007) described the establishment of such collaborative governance structures, thereby unravelling the variables that condition the structure. The structure in a particular system assists in public decision-making procedures about a given area which converges actors' expectations (Emerson et al., p.6). The conditions outlined in the collaborative governance literature represent a large set of possible conditions and configurations (i.e. combination of conditions) that can be present or absent in practice. Both Ansell and Gash (2007) and Emerson et al. (2012) saw the stages within a CGS as a cyclical and iterative process, which comprises elements of trust-building, leadership, creating a shared understanding, commitment, and institutional design. Hence, CGSs take on different shapes and configurations depending on their environment and the actors. Ansell and Gash are clear and advise researchers to study such structures with a contingency approach (p. 562). Contingency theory proposes that different structures within different (system) contexts develop different arrangements, rules, and procedures, as they have to adapt to their environment. Next, we identify four important conditions described in the literature as key to the durability of CGSs.

Many governance collaborations commence with resource asymmetries between public, private, and civil organizations (Ansell and Gash 2007). Often these resource asymmetries have to do with knowledge and expertise, but one of the key and more tangible conditions is an (un)equal balance in resources in terms of finances, means, and assets; in other words, financial (in)dependence. When starting a CGS, financial resources can be put into the process by a public or private partner of the CGS without strings attached. However, more often, due to funding schemes and related accountability measures, allocating budgets leads to resource and subsequently power asymmetries in the partnership between a principal and an agent relation (Van Slyke 2007). Financial independence of the structure and having a dedicated budget for the CGS as a whole is one aspect that positively influences joint governance (Carey and Crammond 2015). It brings about capacity for joint action (Emerson, Nabatchi, and Balogh 2012). Whenever a structure has its own revenues and business model and is therefore financially independent, the power is much more equally distributed within the CGS and with external partners. Being financially independent, for instance as a result of multiple sources of revenue is a way to create a dedicated budget for the garden and reduce the power asymmetries between the actors within the CGS, for instance between a subsidy provider and the CGS. Moreover, financial independence gives leeway to reinvest in the development and maintenance of the structure.

Both Emerson, Nabatchi, and Balogh (2012) and Milward and Provan (2006) illustrated that durable collaborative networks necessitate more elaborated structures and procedures for the activities and management of the work and partnership. This is in accord with what Ansell and Gash (2007) described as institutionalization (or institutional design; i.e. the rules of engagement (Ostrom 2005)). These rules affect relations between actors and the capacity of the collective to successfully govern an issue (Scharpf 2000, 764). In fact, rules are created whenever people collaborate, 
whether it is after a period of time or immediately when the collaborative endeavour starts. Sometimes institutions result from a fierce debate; other times they grow organically. Often these rules embody the dynamics of previous interactions, political or personal views, and power relations (Gupta et al. 2010, 460). They may lead to inflexibility and obstruction. Therefore, the extent to which the structure is institutionalized may help explain why a CGS is durable or not.

To initiate and endure the collaboration, associations and collaborations need to have support. At a minimal level, this refers to principled engagement and shared motivation of an internal board or core group (Emerson, Nabatchi, and Balogh 2012) towards a common goal. In a similar vein, Healey $(1998,1541)$ argued that for a wellfunctioning local initiative, one needs an engaged external network of people, which may involve businesses, non-profit organizations, communities, and/or the public as a whole (Bryson, Crosby, and Middleton Stone 2006, 44). She stressed that in addition to an engaged core team of actors, they need to have dense, strong ties with external actors. This is called social capital (Armitage, Berkes, and Doubleday 2010; Putnam 2000). Broad support of both the core group and external actors summarizes the cyclical process of trust and legitimacy building as described by Ansell and Gash (2007). These authors mentioned that commitment of the involved actors is an essential factor for a well-functioning collaboration.

Ansell and Gash (2007) found that collaborations often have multiple leaders who possess the facilitative skills of convening, mediating, and catalysing. The last condition is, therefore, shared leadership (Ansell and Gash 2007, 550). ${ }^{1}$ Ansell and Gash (2007) stressed in their literature review that leadership is important in two respects: 1) bonding and bringing people together and 2) mediating when the parties reach difficult events in the process. Such leaders need to have the capacity to actively promote participation, ensure real impact, steer the process and outcome of the involved parties, create productive group dynamics, and frame the scope of the process (Ansell and Gash 2007, pp. 553-4). Sørensen and Torfing (2012, 8) distinguished conveners, leaders who bring people together, create arenas, and set the agenda from mediators. These are leaders who mediate different interdependencies, help solve disagreements, and establish a common vision. Thirdly, catalysts are people who try to add new elements, such as knowledge or people, and they can have an overview of risks and opportunities. In CGSs, leaders have to create inter-person and inter-organization collaborative capacity, and thus have to create 'cooperative dispositions and mutual understanding of the individuals who are trying to work together on a common task' (Bardach 1998, 307). This aligns with the ideas of Emerson, Nabatchi, and Balogh $(2012,15)$, who stressed that: 'collaborative governance demands and cultivates multiple opportunities and roles for leadership (Agranoff and McGuire 2003; Bryson, Crosby, and Middleton Stone 2006). These include the leadership roles of sponsor, convener, facilitator/mediator, representative of an organization or constituency, science translator, technologist, and public advocate, among others.' Ansell and Gash (2007) elaborated upon different roles and functionalities of leaders in the collaborative process. In general terms, multiple leaders should foster the collaboration with supportive actions. Hence, shared leadership.

As we cannot include all the elements of Ansell and Gash (2007) and Emerson, Nabatchi, and Balogh (2012), we selected the aforementioned major elements that could explain the durability of the CGSs. These conditions are presented in the literature reviews of Ansell and Gash (2007) and Emerson, Nabatchi, and Balogh 
Table 1. Selection of important conditions.

\begin{tabular}{|c|c|c|}
\hline Ansell and Gash (2007) & Emerson, Nabatchi, and Balogh (2012) & Condition \\
\hline $\begin{array}{l}\text { Starting conditions (resource } \\
\text { asymmetry) }\end{array}$ & Resources - Capacity for joint action & $\begin{array}{l}\text { Financial } \\
\text { independence }\end{array}$ \\
\hline Institutional design & $\begin{array}{l}\text { Procedural and institutional arrangements - Capacity } \\
\text { for joint action }\end{array}$ & Institutionalization \\
\hline Commitment & Principled engagement/shared motivation & Broad support \\
\hline Facilitative leadership & Leadership - Capacity for joint action & Shared leadership \\
\hline
\end{tabular}

(2012) and are conditions for the four 'building blocks' as presented by Ansell and Gash (2007), that is starting conditions; institutional design; collaborative process; and facilitative leadership. We construct the following expectation, based on the idea of contingency: If the CGS has a clear institutional design, is financially independent, is led by shared leadership to guide the process through difficult patches, and builds enough support among both the core team and external actors, the collaborative governance structure is expected to be durable. We summarize the conditions in Table 1, with reference to both Ansell and Gash (2007), and Emerson, Nabatchi, and Balogh (2012).

\section{Urban gardens as examples of collaborative governance structures}

Collaborative governance scholars have unravelled which conditions are important both at the start of a collaboration and during the collaborative process. However, it is unclear how these conditions configure and to what extent this configuration of a CGS can explain the durability of an urban garden. Urban gardens are a good example of collaborative governance because to create and maintain an urban garden, public and private actors work collectively towards an outcome: the garden, and later to maintain this joint outcome. Within this collaboration, public and private actors have a specific role that is often formalized into an agreement or consortium. These roles can be complementary or conflicting at times. In general, public actors have a facilitative role. For instance, they provide a plot, financial support, or a boundary spanner (actors who manage the interface between organizations and their environment (van Meerkerk and Edelenbos 2014, 6) who actively supports the garden and its activities. Most private actors, such as professional gardeners or suppliers, but also volunteers or community organizations, have a more practical role. An urban garden is sometimes a temporary activity; in other cases, the initiative is prolonged and continued as an embedded practice. In our cases, we see that the future of some urban gardens is relatively certain (at the same plot or is moved to another plot). In other cases, the future is uncertain and sometimes the urban garden has already been discontinued. Urban gardens are common in the Netherlands. The database of 'Groen Dichterbij' contained 798 plots in 2016 (Aryawan et al. 2016).

In order to conduct our analysis, we selected gardens that were similar to four criteria. First, the garden is the result of a collective effort (i.e. multiple actors were involved in the fundamental aspects of the initiation of the garden, the establishment, and the maintenance of the garden). Second, since we are interested in the durability of these gardens, every garden has existed for at least three years. Third, these gardens are located in an urban area. We included this criterion to make sure that the context in which the gardens are embedded is relatively similar in terms of the neighbourhoods, possible resources streams, etc. Fourth, in order to enhance the 
similarity between the cases, we selected gardens that all serve a similar purpose. They are all initiatives launched to create urban gardens and to make cities greener and more flood-resistant.

The urban gardens are studied via interviews with key actors (i.e. [former] active volunteers, civil servants, and employees of involved housing corporations and social entrepreneurs). We interviewed at least two involved actors from each urban garden, resulting in a total of 36 respondents. The respondents were interviewed in the period from April 2017-February 2018. The interviews were semi-structured. In addition to introductory questions about the garden, its origin, context, and functioning in general, we asked all respondents the same questions with regard to the durability of the garden and about the four conditions as described above (see also Table 1). These answers were used to generate the scores on the various conditions. We also conducted site visits and a document study. Table 2 shows an overview of the urban gardens. With respect to the revenues, we indicated only the revenues generated by activities within the garden; funds and subsidies are indicated with the phrase 'financially dependent on third party.'

\section{The research method: fuzzy set qualitative comparative analysis}

To understand which combinations of conditions lead to the durability or discontinuation of an urban garden, we used FsQCA, a qualitative method and approach that describes cases as configurations (i.e. combinations) of conditions. The method offers a unique way to unravel empirical combinations of conditions in a dataset of cases related to a certain outcome (Ragin 1987; Rihoux and Ragin 2008; Schneider and Wagemann 2012). 'Conditions' are what we call independent variables in common statistical methods. The outcome is generally referred to as a dependent variable (Rihoux and Lobe 2009). FsQCA requires the assignment of a certain score to cases in a particular set. A set is a collection of objects with particular characteristics. For example, the case of Halte Westplein - an urban garden in the middle of a busy intersection - scores low if we look at the set of urban gardens with extensive formalization (in fact, institutionalization is absent).

Outcome

To conduct a FsQCA, both the conditions and the outcome need to be translated to fuzzy-set categories (Ragin 2008b; Schneider and Wagemann 2010b), which is a finegrained way to explain what kind of membership (i.e. score) a case has in a certain set (Schneider and Wagemann 2010a). The outcome in our study, durability, is operationalized as whether an urban garden still exists after three years. Although some gardens were set up as temporal, others still exist. Next, the conditions that we selected in the theoretical section on collaborative governance structures were also translated in four-value fuzzy sets. These four-value fuzzy sets are described as displayed in Table 3.

In this study we consider financial (in-) dependence of the CGS as the most tangible condition for possible resource asymmetries among actors. Some gardens deliberately decided not to develop a business model or were not successful in developing one; as a result, they are financially dependent. We scored these gardens a 0. Gardens which turn to traditional ad-hoc fundraising or received seed money scored 0.33. Gardens that count on grants and long-term contracts from foundations and government sources received a 0.66 on the scale of financial independence. Gardens that are fully 


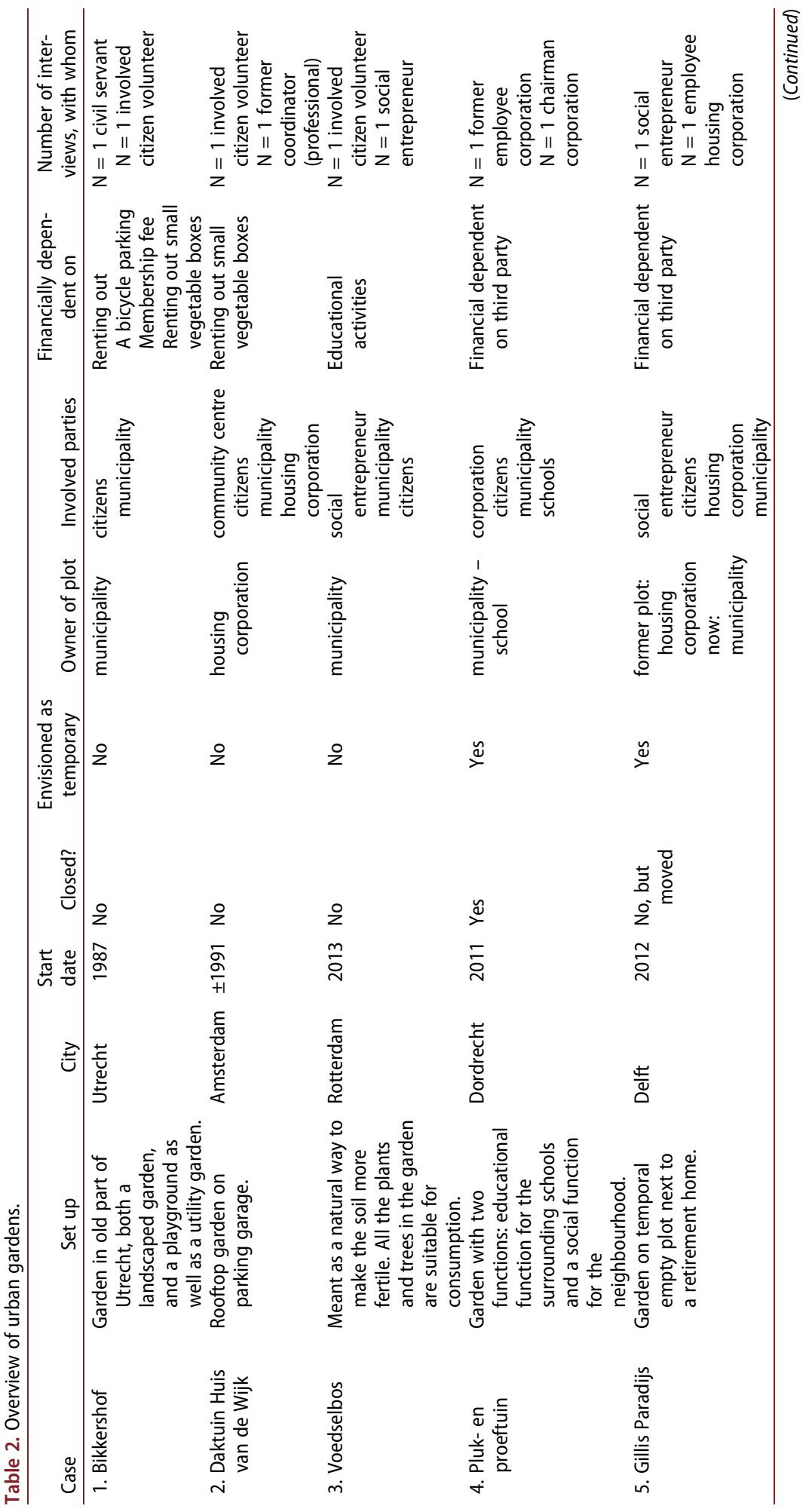




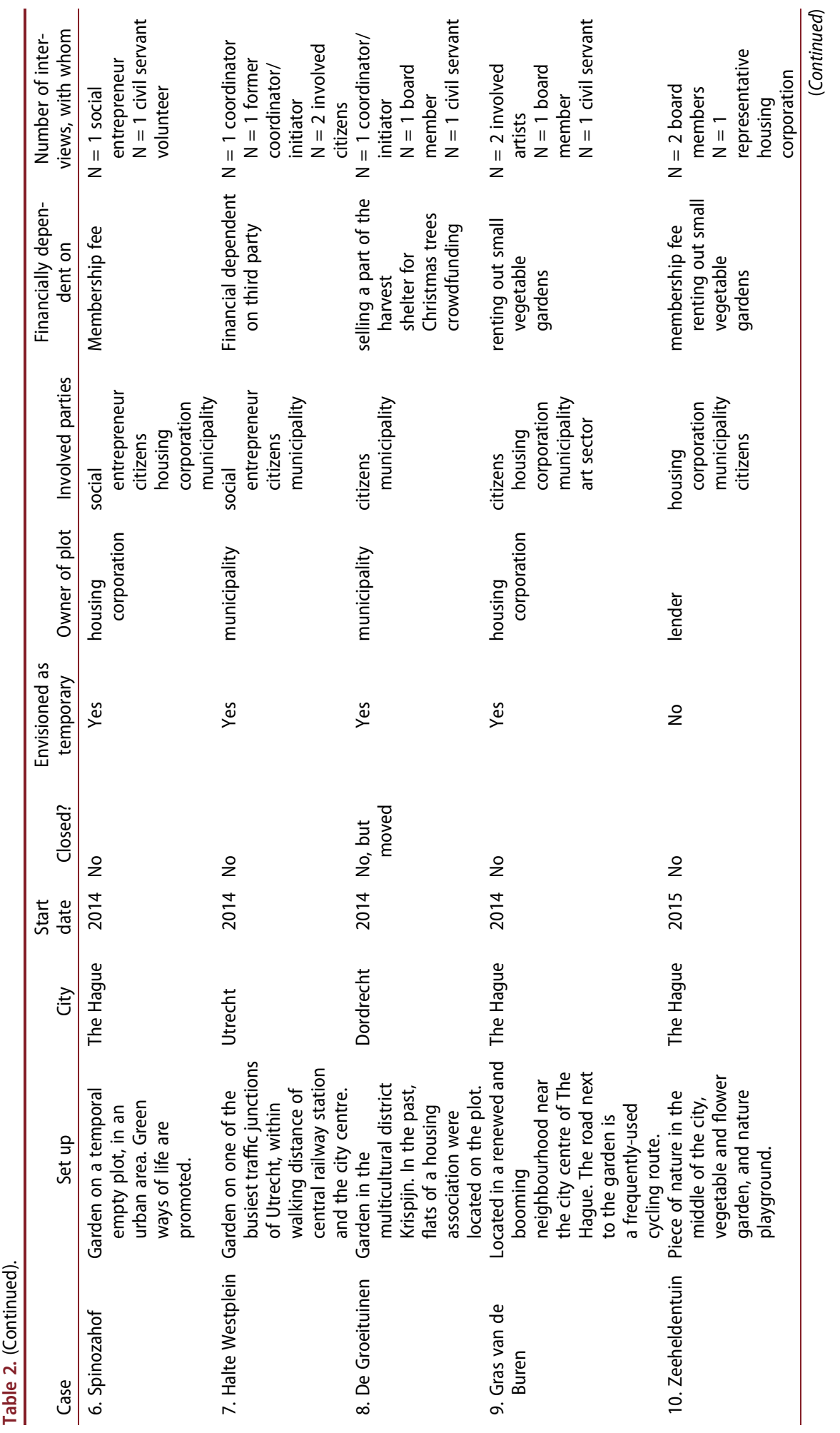




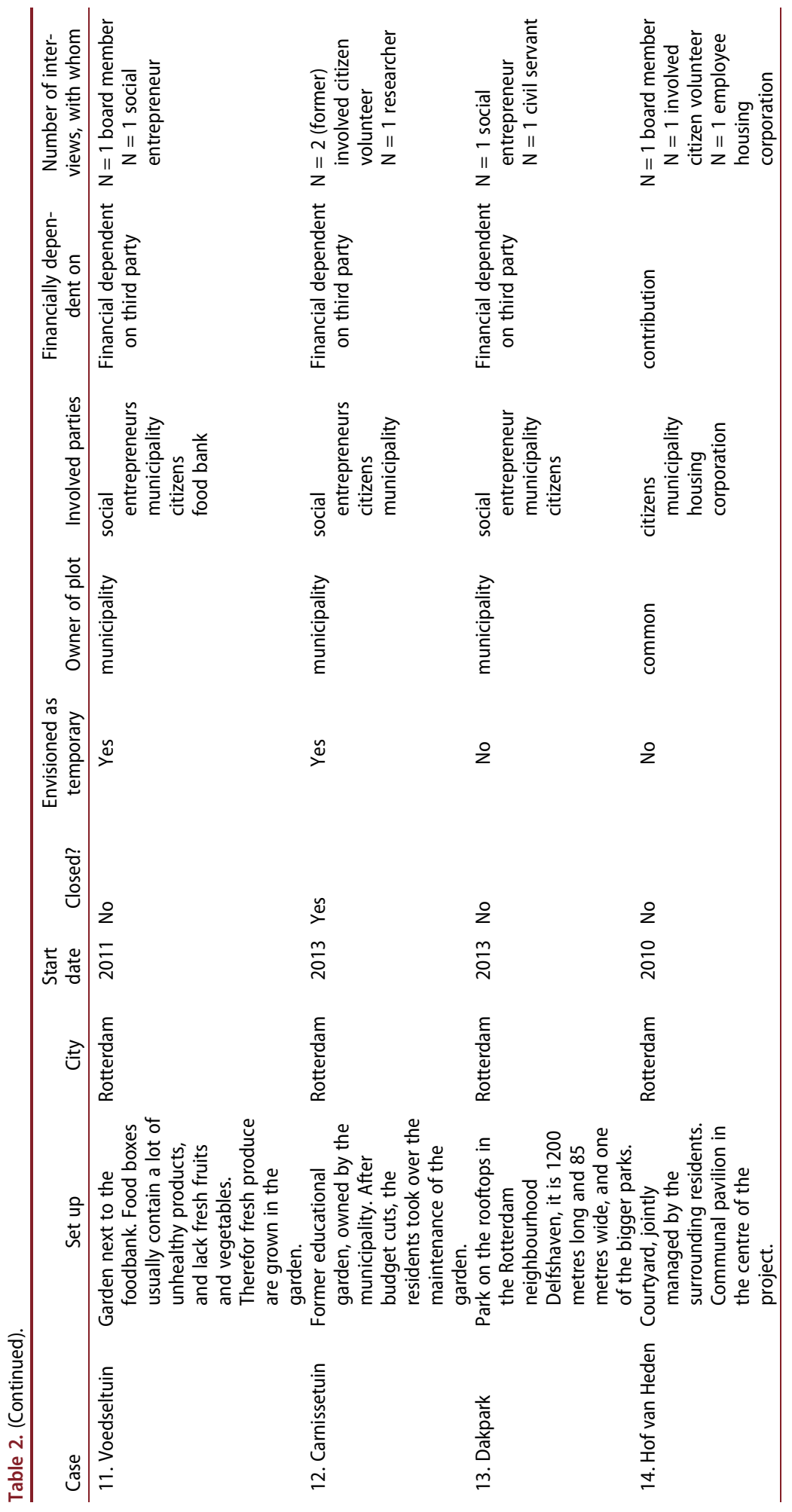


Table 3. A four-value fuzzy set.

\begin{tabular}{ccc}
\hline \multicolumn{1}{c}{ Condition } & Outcome \\
\hline $\begin{array}{c}1=\text { Fully in the } \\
\text { set }\end{array}$ & $\begin{array}{c}\text { a high degree of a particular } \\
\text { condition }\end{array}$ & $\begin{array}{c}\text { This means the garden still exists after } 3 \text { years and its future } \\
\text { is relatively certain (meaning that the garden is not } \\
\text { expected to be discontinued any time soon). }\end{array}$ \\
$\begin{array}{c}0,66=\text { Mostly in } \\
\text { the set }\end{array}$ & $\begin{array}{c}\text { a moderate degree of } \\
\text { a particular condition }\end{array}$ & $\begin{array}{c}\text { This means that the garden still exists, but the future } \\
\text { perspective is uncertain }\end{array}$ \\
$\begin{array}{c}\text { out of the set. } \\
\text { partial (but not full) absence } \\
\text { of a particular condition } \\
\text { the set. }\end{array}$ & $\begin{array}{c}\text { The garden still exists, but this garden will be discontinued } \\
\text { soon }\end{array}$ \\
\hline
\end{tabular}

independent and have multiple revenue sources scored a 1, which indicates that they are fully in the set of financially independent urban gardens.

Some gardens are loosely organized and not overly formal. These gardens scored a 0 ; in other words, strong institutionalization is absent. Sometimes, the garden is semi-attached to an organization, but autonomous. These gardens score 0.33 on institutionalization. If the garden is led by a social entrepreneur, as way of organizing the organization, communication and activities it scored 0.66 . When a garden is laid down in a legal form, the rules of the game are more formal and the garden scored a 1 in terms of institutionalization. We include institutionalization as a condition for institutional design (Ansell and Gash 2007) and procedural arrangements (Emerson, Nabatchi, and Balogh 2012).

We operationalize broad support as a cumulative condition. If the garden has not engaged a strong core group and is struggling to find support, it scored 0 . Whenever there is a strong but small core group it scored 0.33 , and when it has both a strong core group and a strong second layer of active volunteers, it scored 0.66 . The highest score of 1 is given when a garden has the aforementioned characteristics, as well as links with umbrella organizations, government, and businesses.

Shared leadership is seen as a cumulative condition, if the collaborations have multiple leaders: conveners, mediators, and catalysts shared leadership is present (Ansell and Gash 2007). The collaboration scored 0 if none of the skills is present, a 0.33 if one of the elements is present, and so on. In Table 4, an overview is provided of all four conditions, the set-membership scores, and their qualitative labels.

Including more conditions in our model could have led to a more insightful analysis, however this is not good practice. As we have only a small sample (N-14), analysing more conditions would lead to higher probability of generating results on random data. This is based on the benchmark for the occurrence of contradictions developed by Marx and Dusa (2011).

Analysis

To conduct the actual fsQCA itself, we used RStudio and the QCA (GUI) package in $\mathrm{R}^{2}$ (Duşa 2007), and the excellent and insightful manual of Thomann and Wittwer (2017). By means of the software, we investigated the necessary conditions, which is a first step and good practice, as an analysis based on sufficiency can lead to false claims about necessity (Schneider and Wagemann 2010b). If a condition is necessary for the durability of an urban garden, a particular condition is consistently present or absent. Afterwards, a sufficiency analysis is conducted. Sufficiency means that a condition (or a combination) leads consistently to a particular outcome (the durability of an urban garden; e.g., Benoît Rihoux and Lobe 2009; Schneider and 
Table 4. Overview of conditions.

\begin{tabular}{|c|c|c|c|c|}
\hline & $\begin{array}{l}\text { Condition } 1 \text { - } \\
\text { financial } \\
\text { independence }\end{array}$ & $\begin{array}{l}\text { Condition 2: Strong } \\
\text { institutionalization }\end{array}$ & $\begin{array}{l}\text { Condition 3: broad } \\
\text { support }\end{array}$ & $\begin{array}{c}\text { Condition } 4 \text { - shared } \\
\text { leadership }\end{array}$ \\
\hline $\begin{array}{l}1=\text { Fully in the } \\
\text { set }\end{array}$ & $\begin{array}{l}\text { Commercial } \\
\text { activities, } \\
\text { fees for } \\
\text { services }\end{array}$ & $\begin{array}{l}\text { The urban garden is laid } \\
\text { down in a legal form } \\
\text { (e.g. an association) }\end{array}$ & $\begin{array}{l}\text { Active support of } \\
\text { organizations } \\
\text { able and willing } \\
\text { inner circle, } \\
\text { neighbourhood; } \\
\text { and (semi-public) } \\
\text { organizations }\end{array}$ & $\begin{array}{l}\text { Conveners, } \\
\text { mediators and } \\
\text { catalysts are } \\
\text { present within the } \\
\text { urban garden }\end{array}$ \\
\hline $\begin{array}{l}0,66=\text { Mostly in } \\
\text { the set }\end{array}$ & $\begin{array}{l}\text { Grants and } \\
\text { contracts } \\
\text { from } \\
\text { foundations } \\
\text { and } \\
\text { government } \\
\text { sources }\end{array}$ & $\begin{array}{l}\text { The urban garden is led } \\
\text { by a (social) } \\
\text { entrepreneur }\end{array}$ & $\begin{array}{l}\text { Strong inner circle, } \\
\text { strong relations } \\
\text { with either the } \\
\text { neighbourhood or } \\
\text { the local } \\
\text { government }\end{array}$ & $\begin{array}{l}\text { Two of the } \\
\text { characteristics of } \\
\text { facilitative } \\
\text { leadership are } \\
\text { present within the } \\
\text { urban garden }\end{array}$ \\
\hline $\begin{array}{l}0,33=\text { Almost } \\
\text { out of the set }\end{array}$ & $\begin{array}{l}\text { Traditional ad- } \\
\text { hoc } \\
\text { fundraising } \\
\text { (seed } \\
\text { money) }\end{array}$ & $\begin{array}{l}\text { The garden is part of } \\
\text { a larger organization }\end{array}$ & $\begin{array}{l}\text { Strong inner circle, } \\
\text { ad-hoc relations } \\
\text { with the } \\
\text { neighbourhood }\end{array}$ & $\begin{array}{l}\text { One of the } \\
\text { characteristics of } \\
\text { facilitative } \\
\text { leadership is } \\
\text { present within the } \\
\text { urban garden }\end{array}$ \\
\hline $\begin{array}{l}0=\text { Fully out of } \\
\text { the set }\end{array}$ & $\begin{array}{l}\text { No business } \\
\text { model, } \\
\text { Financial } \\
\text { problems }\end{array}$ & $\begin{array}{l}\text { The governance is } \\
\text { loosely organized (no } \\
\text { legal form, no leading } \\
\text { entrepreneur and not } \\
\text { a part of a bigger } \\
\text { organization). }\end{array}$ & $\begin{array}{l}\text { Lack of strong } \\
\text { shoulders }\end{array}$ & $\begin{array}{l}\text { None of the } \\
\text { characteristics of } \\
\text { facilitative } \\
\text { leadership are } \\
\text { present }\end{array}$ \\
\hline
\end{tabular}

Wagemann, 2010a). For the analysis of sufficient conditions, we first constructed a truth table using the software, which is in essence a mathematical table that shows how many cases adhere to a logical combination. This is done on the basis of binary numbers: 1 means the presence of a certain condition, and 0 means the absence of a certain condition. For instance, the Bikkershof scores 1-1-1-1 on the conditions and on the outcome 1, which means that all the conditions are present and the urban garden survived. The software surveys all the cases and counts how many adhere to or abandon this pattern, which is how it calculates how many cases consistently lead to the same outcome (either discontinuation or durability of an urban garden; Schneider and Wagemann 2012).

Two parameters are important to assess whether a certain condition or configuration is necessary or sufficient: consistency and coverage. Consistency is most important and indicates the extent to which a condition consistently leads to the same outcome (existence or discontinuation). If many cases contradict a certain pattern, this parameter drops. We set the necessity consistency threshold to 0.9 and the sufficiency consistency threshold close to $0.8^{3}$ (Schneider and Wagemann 2010b) to avoid deviant cases in terms of consistency. Coverage is the extent to which cases are either covered or entail this particular condition (or combination of conditions). This parameter is considered by QCA scholars to be less important compared to the consistency score, as it is not the number of cases which is important but the mechanism or the case knowledge about the particular configuration. A configuration represented by only 
one case can be interesting, for instance, to strengthen knowledge on a particular mechanism (Schneider and Wagemann 2010b, 412).

If a particular pattern is consistent, the researcher takes these cases into the minimization analysis, which can be summarized as: 'If two configurations differ in only one condition, but show the same outcome, this particular condition can be eliminated' (Schneider and Wagemann 2012, 105). The researcher ends up with 'simple' paths explaining durability and discontinuation.

The configurations in the following paragraphs show the conservative solution, which only takes into account truth table rows with empirical evidence (i.e. the rows that contain at least one case; Schneider and Wagemann 2012). Which means that we were very modest when analysing and interpreting, only the data 'as is' is taken into account. In the figures, however, we go one step further. Fiss (2011) showed how we can build causal theories by combining the conservative with the parsimonious solution. This latter solution takes into account logical remainders as well, i.e. a row without empirical material. This means that in order to minimize the paths, this solution takes into account rows that are not portrayed by any case. The parsimonious solution is what you get if you take the minimization further than the conservative solution, and go to the simplest path. The bold conditions are the conditions both present in the conservative and the parsimonious solution, and therefore: core conditions. The parsimonious solution considers additional rows and shows which conditions are most distinct (see Appendix A). The idea to present the paths as real pathways towards an outcome is based on the work of Raab and Stuppert (2014). ${ }^{4}$

\section{Results}

In Table 5, the raw data matrix is shown.

\section{Are there necessary conditions?}

When we examine the durable urban gardens, we cannot detect a single necessary condition which is present or absent in the gardens. Neither did we find necessary conditions in the discontinued cases. We can conclude that the explanation of why

Table 5. Raw data matrix.

\begin{tabular}{lccccc}
\hline Cases & $\begin{array}{c}\text { Financial } \\
\text { independence }\end{array}$ & $\begin{array}{c}\text { Strong } \\
\text { institutionalization }\end{array}$ & $\begin{array}{c}\text { Broad } \\
\text { support }\end{array}$ & $\begin{array}{c}\text { Shared } \\
\text { leadership }\end{array}$ & Durability \\
\hline Bikkershof & 0,66 & 1 & 1 & 0,66 & 1 \\
Daktuin - Huis van de Wijk & 1 & 0,33 & 0,66 & 0,33 & 0,66 \\
Voedselbos & 1 & 0,66 & 0,33 & 0,33 & 0,66 \\
Pluk- en proeftuin & 0,33 & 0,33 & 0,66 & 0,33 & 0 \\
Gillis Paradijs & 0,66 & 0,66 & 1 & 1 & 1 \\
Spinozahof & 0,33 & 0,66 & 0,66 & 1 & 0,33 \\
Halte Westplein & 0,33 & 0 & 0,33 & 0 & 0,33 \\
De Groeituinen & 1 & 1 & 1 & 1 & 1 \\
Gras van de Buren & 0,33 & 1 & 0,33 & 0,33 & 0,66 \\
Zeeheldentuin & 0 & 1 & 0 & 0,66 & 0,66 \\
Voedseltuin & 0,66 & 0,66 & 1 & 1 & 0,66 \\
Carnissetuin & 0,66 & 0,66 & 0,66 & 1 & 0 \\
Dakpark & 0,33 & 1 & 0,66 & 1 & 1 \\
Hof van Heden & 0,33 & 1 & 0 & 0,66 & 1 \\
\hline
\end{tabular}


a certain garden is durable or not is more complex and does not depend upon individual conditions as such. Therefore, we subsequently analyse the (combinations of) conditions for durability. The following paragraph investigates these configurations (i.e. the combination of conditions that might lead to the durability or the abolishment of an urban garden).

\section{Are there sufficient conditions?}

First, we built a truth table (see Table 6), that shows which configurations the cases portrait. We set the threshold for consistency at 0.79 because this is a good practice (Wagemann and Schneider - standards for good practice). This includes the upper four truth table rows in the analysis (i.e. minimization process). This analysis of sufficient (combinations of) conditions shows three distinct configurations to durability. These cover eight cases.

Financial independence is a core condition in most configurations, which is depicted by the fact that in four out of five successful cases, financial independence is considered high. In another configuration covering two cases, the combination of

Table 6. Truth table for durable gardens.

\begin{tabular}{|c|c|c|c|c|c|c|c|}
\hline $\begin{array}{l}\text { Financial } \\
\text { independence }\end{array}$ & $\begin{array}{l}\text { Strong institutio- } \\
\text { nalization }\end{array}$ & $\begin{array}{l}\text { Broad } \\
\text { support }\end{array}$ & $\begin{array}{c}\text { Shared } \\
\text { leadership }\end{array}$ & Outcome & Cases & Cons. & PRI \\
\hline 1 & 1 & 0 & 0 & 1 & Voedselbos & 0.83 & 0.66 \\
\hline 1 & 1 & 1 & 1 & 1 & $\begin{array}{l}\text { DeGroeituinen, GillisParadijs, } \\
\text { Bikkershof, Voedseltuin, } \\
\text { Carnissetuin }\end{array}$ & 0.82 & 0.75 \\
\hline 1 & 0 & 1 & 0 & 1 & DaktuinHuisvandeWijk & 0.80 & 0.49 \\
\hline 0 & 1 & 0 & 0 & 1 & GrasvandeBuren & 0.80 & 0.66 \\
\hline 0 & 1 & 0 & 1 & $?$ & & & \\
\hline 0 & 1 & 1 & 1 & $?$ & & & \\
\hline 0 & 0 & 1 & 0 & $?$ & & & \\
\hline 0 & 0 & 0 & 0 & $?$ & & & \\
\hline 1 & 0 & 0 & 0 & Logical remainder & & & \\
\hline 0 & 0 & 0 & 1 & Logical remainder & & & \\
\hline 1 & 0 & 0 & 1 & Logical remainder & & & \\
\hline 1 & 1 & 0 & 1 & Logical remainder & & & \\
\hline 0 & 1 & 1 & 0 & Logical remainder & & & \\
\hline 1 & 1 & 1 & 0 & Logical remainder & & & \\
\hline 0 & 0 & 1 & 1 & Logical remainder & & & \\
\hline 1 & 0 & 1 & 1 & Logical remainder & & & \\
\hline
\end{tabular}
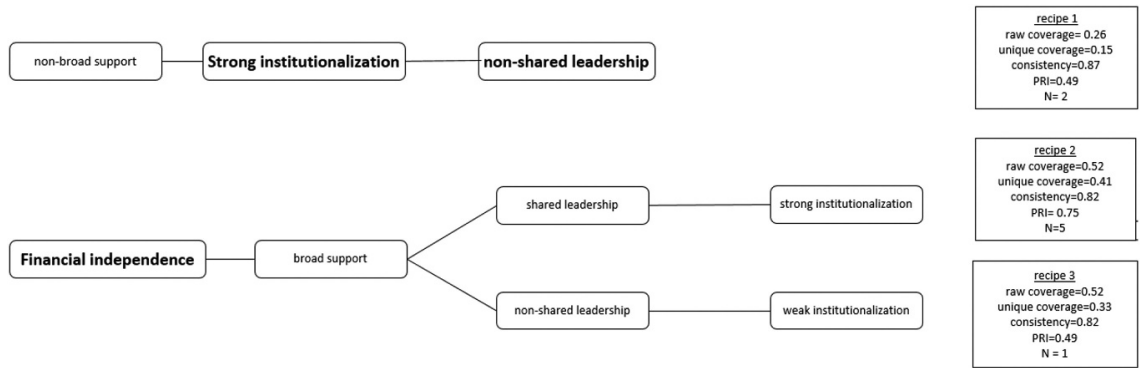

Figure 1. Analysis of sufficient conditions - configurations for DURABILITY. solution coverage: 0.74solution consistency: 0.87PRI: $0.81 \mathrm{~N}=8$ 
a small group and strong institutionalization is core to the explanation of why the garden has continued. Figure 1 shows which configurations lead to a durable urban garden. ${ }^{5}$ The following paragraph analyzes the cases to look for the mechanisms, based on the configurations, that explain their survival.

Configuration 1: absence of broad support, strong institutionalization, non-shared leadership $\rightarrow$ durable garden

This is a configuration that explains two gardens. Gras van de Buren is a relevant illustration of this configuration. This garden started when a nearby theatre and neighbours independently contacted the housing association, asking whether they could start a green project on their undeveloped plot. The housing association suggested the formation of a workgroup to further develop this plan. Especially the residents who had recently moved into the district were involved. Soon the workgroup encountered a problem: there was not enough budget to develop the project, leading to a standstill. After approximately two years, the municipality of The Hague contacted a volunteer to ask about the status of the project. This conversation led to financial support of the municipality, since this project aligned perfectly with its policy to improve the neighbourhood. The partnership between the neighbourhood, the municipality and the housing association is now defined in a formal agreement. This document was necessary to institutionalize the responsibilities and resources of the different actors and to determine the pact between the different parties. To be part of this covenant, the neighbours needed to establish the project in a legal form, therefore the urban garden now has an official board. Besides this formalization the responsibilities between the neighbours are loosely defined. The board members are performing their tasks on an ad-hoc basis. Although, Gras van de Buren was envisioned to be temporarily, nowadays the structure and support are that well-developed that it seems to be a more durable garden.

Configuration 2: financial independence, broad support, shared leadership, strong institutionalization $\rightarrow$ durable garden

Most urban gardens that endured $(\mathrm{N}=5)$ share that they are financially independent, have shared leadership and broad support, and are institutionalized in a certain structure, such as a foundation or association. These cases all have diversified business models and are therefore (almost) financially independent. Bikkershof, for instance, generates revenue through bicycle parking which is then reinvested in the garden. $D e$ Groeituinen developed a business model with multiple revenues by, for instance, selling its harvest at a market and a Christmas tree farm.

Furthermore, these five gardens received support from various stakeholders. De Groeituinen receives support from the municipality, as the project fits perfectly into the municipal policy to stimulate citizen participation. Additionally, the municipality saw opportunities to enhance social cohesion in the neighbourhood with this project. To coordinate the project, a board was formed, consisting of members who value self-sufficiency. Therefore, it wanted to arrange the resources needed for the project themselves: 'We try not to use the subsidy of the municipality, we will only use it if we are not capable anymore to find funds ourselves.' De Groeituinen is also supported by a group of 20 to 25 volunteers involved in the maintenance of the project. Bikkershof also received financial support from both the municipality and neighbours. While it can be a challenge to find enough willing volunteers, up to now the project has succeeded in finding enough helping hands to maintain the garden. 
Another characteristic of these five gardens is shared leadership. For example, Gillis Paradijs is governed by a professional foundation that was hired by the housing association and had the task to set up the preconditions for a flourishing garden. Examples of tasks include organizing activities and ensuring that the rules are followed. After five years at a plot of the housing association, the garden had to move. The professionals were rehired by the municipality to accommodate the relocation. The professionals are not only convening neighbours by organizing activities but are also active mediators who maintain contact with the different stakeholders.

The last characteristic of these five gardens involves a high level of institutionalization. All the gardens were registered in a legalized form. De Groeituinen, for instance, is formalized in an association which is governed by a board. The board has the ambition to scale up the CGS to an organization that hosts people with a distance from the labour market. De Groeituinen, Gilles Paradijs, and the Voedseltuin were envisioned to be temporary; however, the structure and support are so well developed that they seem to be a more durable garden.

An outlier (a deviant case in consistency; Schneider and Rohlfing 2013) is the Carnissetuin, a garden that was discontinued, although all the conditions that led other structures to success were present. The Carnissetuin started out in an existing abandoned facility (an educational garden), and as a temporary garden. A collective of entrepreneurs called Creatief Beheer (creative maintenance), initiated a plan called Resilience in collaboration with a network of organizations. The Carnissetuin was one of the many projects of this plan. However, the plot on which the Carinessetuin was hosted was eventually sold to a project developer. The municipality never contacted the Carnissetuin staff about this, which caused protests and conflicts. Consequently, the garden was discontinued. This case shows that other factors influenced the durability of this garden. While the conditions considered in this manuscript are more alike internal factors of the structures, external conditions led to its discontinuation.

Configuration 3: financial independence, broad support, non-shared leadership, absence of strong institutionalization $\rightarrow$ durable garden

This configuration was a recipe for success for one garden, Daktuin Huis van de Wijk. It is only possible to enter the garden (which is on the roof of a parking garage) through a community centre. The project is financially independent, because residents can rent a part of the garden for 50 euro per year. The project is well supported by other actors. Its community centre provides utilities for the garden, such as electricity. The project also receives support from active neighbours. Each Thursday morning neighbour volunteers work in the garden.

Within Daktuin Huis van de Wijk, there is not a well-defined leader. Leadership is distributed among the involved neighbours: each have their own task (e.g., finance, sponsors, or new residents). The community centre is also important, because it is (legally) responsible for the Daktuin. The housing association created a protocol, to which the involved participants comply. If the protocol is violated, the community centre is accountable. 
Table 7. Truth table.

\begin{tabular}{|c|c|c|c|c|c|c|c|}
\hline $\begin{array}{l}\text { Financial inde- } \\
\text { pendence }\end{array}$ & $\begin{array}{l}\text { Strong institutio- } \\
\text { nalization }\end{array}$ & $\begin{array}{l}\text { Broad } \\
\text { support }\end{array}$ & $\begin{array}{c}\text { Shared } \\
\text { leadership }\end{array}$ & Outcome & Cases & Cons. & PRI \\
\hline 0 & 0 & 0 & 0 & 1 & HalteWestplein & 1 & 1 \\
\hline 0 & 0 & 1 & 0 & 1 & Plukenproeftuin & 1 & 1 \\
\hline 1 & 0 & 1 & 0 & 0 & & & \\
\hline 1 & 1 & 0 & 0 & 0 & & & \\
\hline 0 & 1 & 0 & 0 & 0 & & & \\
\hline 0 & 1 & 1 & 1 & 0 & & & \\
\hline 0 & 1 & 0 & 1 & 0 & & & \\
\hline 1 & 1 & 1 & 1 & 0 & & & \\
\hline 1 & 0 & 0 & 0 & Logical remainder & & & \\
\hline 0 & 0 & 0 & 1 & Logical remainder & & & \\
\hline 1 & 0 & 0 & 1 & Logical remainder & & & \\
\hline 1 & 1 & 0 & 1 & Logical remainder & & & \\
\hline 0 & 1 & 1 & 0 & Logical remainder & & & \\
\hline 1 & 1 & 1 & 0 & Logical remainder & & & \\
\hline 0 & 0 & 1 & 1 & Logical remainder & & & \\
\hline 1 & 0 & 1 & 1 & Logical remainder & & & \\
\hline
\end{tabular}
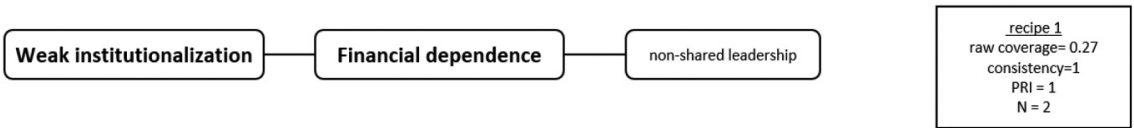

Figure 2. Analysis of sufficient conditions - configuration for discontinuation or non-durability.

\section{Analysis of sufficient conditions of discontinued structures}

Subsequently, we show the configurations for abolishment. First, we constructed a truth table (see Table 7). We set the threshold for sufficient conditions at 0.81 , excluding a clear case of a difference in kind (a case that did survive, Daktuin).

After the minimization process, the analysis of sufficient conditions shows one distinct configuration to discontinuation (Figure 2). The configuration covers two cases (Halte Westplein and Pluk-en Proeftuin). Both these cases were also intended to be temporary. Absence of strong institutionalization and financial dependence are core conditions in this structure. Apparently, it was not necessary for these gardens to set up an institutional design or a business model, since they were intended to be temporary. Figure 2 shows the configuration which led to the discontinuation of the urban garden.

Configuration explaining the absence of durability: absence of strong institutionalization, financial dependence, non-shared leadership $\rightarrow$ discontinuation

Halte Westplein is located in the middle of one of the busiest traffic junctions of Utrecht. In 2013 some local residents wanted to cheer up the grey and bleak intersection. After a consultation with the municipality, they planted flower bulbs in the middle of the crossroads. In the spring of 2014 the project was expanded to include 15 moveable plant boxes in which the neighbours could grow their own vegetables, flowers, and herbs. Thanks to adjustments in traffic regulations, the Halte Westplein project expanded in 2016 into one large plot with a small building and a communal garden and a second plot on the other side of the road with the plant boxes. The project was loosely organized and was not registered as 
a legal entity. In 2017 the formal leader and driving force behind the project quit. Currently, a part of the garden is maintained by a few neighbours.

The project Pluk-en Proeftuin is already discontinued. The garden was located in Dordrecht's most innovative area, called the 'learning park.' A closely knit group of neighbours was engaged in the project, and along with students, they were heavily involved in the garden maintenance. For the students, maintenance was combined with an educational purpose, which kept them committed to the process. The garden budget came from the municipality and donations, but the garden never developed a business plan or institutions to support the durability of the project, as it was envisioned as temporary from the beginning. Involvement declined gradually, as plans for future buildings on the plot were already in place. One of the involved parties explained: 'If it was envisioned as a park, or something like that, it could have survived for a longer period, I can imagine that the involvement of the neighbourhood would be different.'

\section{Discussion and conclusion}

Collaborative governance is heralded as concept to address contemporary policy making and public service delivery. Here, these processes are considered a collective outcome, produced by a network of actors. Most research addressing collaborative governance has focused on the emergence of these structures, rather than offering explanations why these configurations are continued over a longer period of time. In order to address this issue, this paper aimed to understand what factors determine the continuation or the abolishment of a CGS. We found that no single factor can explain such an outcome, but rather a configuration of factors.

In our Qualitative Comparative Analysis (QCA), we build on the contingency theory of Ansell and Gash (2007). In order to do justice to the comprehensiveness of this framework, we translated the theory into four measurable conditions, one for each building block. The condition for resource asymmetry was financial independence; for institutional design, it was level of institutionalization; for collaborative commitment, broad support was our condition; and for facilitative leadership, we used shared leadership. Our analysis shows that none of these conditions can be considered necessary for the durability of CGSs. Basically, our study shows that there is no 'silver bullet' for effective collaborative results. If one wishes to understand effective CGSs, one should focus on the configuration of different influential factors (see Emerson et al. 2012; p 22). In this result, we also recognize the initial approach of Ansell and Gash (2007) by presenting their framework as a configurational framework, meaning that the factors they mention need to be considered in coherence, rather than separately.

Our main contribution to the literature is how our QCA shows that multiple configurations of factors may explain the durability of effectively governed urban gardens. The idea of multiple forms of network governance leading to different kinds of success is not new (see Provan and Kenis 2008). However, this paper illustrates how several ingredients for those configurations (i.e. financial independence, strong institutionalization, and having a small core group of volunteers) lead to a particular kind of network success (endurance). Weak institutionalization, combined with being financially dependent, is essential to understanding the discontinuation of the CGSs. In doing so, our analysis shows: 1) although no single factor in itself can explain the 
durability of a CGS, certain configurations may; and 2) what these configurations are (see Figures 1 and Figures 2 i.e. configuration of small core group; strong institutionalization; and non-shared leadership; configuration of financial independence; shared leadership and strong institutionalization; or configuration of financial independence; non-shared leadership; and weak institutionalization). In doing so, although our conditions are simplifications of the building blocks as identified by Ansell and Gash (2007) and Emerson, Nabatchi, and Balogh (2012), we illustrate in what capacity these blocks can be considered conditional, with regard to the durability of a CGS. Therefore, we add to the conception of what 'effective' means in relations to governance and their networks (Sørensen and Torfing 2009).

The importance of formal rules is particularly interesting, since in the current dominant governance paradigm (Osborne 2006) there is a trend towards more loosely coupled collaborations with multiple stakeholders. Our results indicate that a traditional organizational logic, including fixed responsibilities and accountability structures (Alexander 1995), is important to facilitate (continued) collaboration. This underscores the notion of Emerson, Nabatchi, and Balogh $(2012,15)$ that 'long-lived collaborative networks require more explicit structures and protocols.' Formalizing agreements, rules and codes can help actors make clear what they expect from each other, make interactions predictable, and present themselves as a legitimate organization. Furthermore, institutionalization lowers transaction costs and thus, due to institutionalization, certain patterns of behaviour become easier than others. The importance of institutionalization is also supported by our observation that when such a formalization was absent (even winged by broad support and shared leadership), it would lead to discontinuation of the garden. Therefore, it appears that organizations gain legitimacy (and resources) when they set up structures and/or institutions (Meyer and Rowan 1977).

Also, in one of our cases, we found that even though shared leadership was present throughout the case, the urban garden was discontinued. This is interesting, since Ansell and Gash (2007) introduced facilitative leadership as the key remedy when the collaboration seems to fail. Since our most important result is that several factors, ideally including those analysed in this article and their interplay, should be considered in conjunction for the success of a CGS, our analysis indicates that facilitative leadership is to be supported by other conditions: a small core group; strong formalization; and, most of all, financial independence. This makes sense, since it is much easier to continue a CGS if there are few people. The scale of some CGSs may require dealing with many people. In addition, ideal configurations might vary between recent and long-lived initiatives. Hence, our results offer nuances to key assumptions in public management and governance literature and the role of management in these.

Although our findings both give an interesting nuance and confirmation of some of our theoretical understandings of CGSs, we cannot generalize from our sample. Although we chose urban gardens based upon their collaborative governance characteristics, this sample is not representative of CGSs in a broader view, since it only involves one policy domain. It would be interesting to compare the results of this study to other CGSs in other domains to see if configurations in other domains point to the same direction. Furthermore, although the sample is small, we are confident that our results are valid, based on the consistency thresholds and the ratio between cases and conditions (Marx and Dusa 2011; Schneider and Wagemann 2010b). Last, in our choice of research methods and our ambition to build on the Ansell and Gash framework, we reduced the framework to four conditions. This simplification means that we should be cautious when drawing conclusions regarding our 
additions to and critiques of the existing framework. However, our results make a plausible claim concerning the coherence of influential factors to the durability of CGSs. Moreover, sufficient patterns in the successful cases point to indicate a clear direction of where successful configurations can be found. Therefore, the next step would be to test and validate these configurations in a larger $\mathrm{N}$ setting. That would allow us not only to explain why CGSs continued or not but also to show elaborated insights on required skills and competencies actors involved in CGSs need to have.

\section{Notes}

1. Note: since facilitative leadership is presented in the framework of Ansell and Gash as one block, rather than a collection of several components, it is unnecessary to distill a condition from this block.

2. The QCA script was obtained at the 2017 ECPR winter school course from Carsten Schneider

3. Consistency threshold was 0.79 for the present of durability and 0.81 for the absence of durability. The frequency threshold was set to 1 .

4. https://assets.publishing.service.gov.uk/media/57a089b440f0b652dd00037e/61259-Raab _Stuppert_Report_VAWG_Evaluations_Review_DFID_20140626.pdf

5. The paths portrait a mix of conditions, and not an order or sequence.

\section{Acknowledgments}

This paper was based on an inventory of blue and green infrastructures in urban areas, funded by the European Commission's Interreg North Sea Region project called BEGIN (Blue-Green Infrastructures through Social Innovation).

\section{Disclosure statement}

No potential conflict of interest was reported by the author(s).

\section{Notes on contributors}

Dr. Astrid Molenveld is assistant professor at the Department of Public Administration of the Erasmus University Rotterdam and University of Antwerp. Her current research activities include comparative research on coordination and collaborative governance, with a special focus on cross-cutting and 'wicked' policy issues, and community self-organization in the climate adaptation, health, youth and welfare sector. Email: Molenveld@essb.eur.nl Postal address: Burgemeester Oudlaan 50, 3062 PA Rotterdam, Netherlands

Dr. William Voorberg is the coordinator of the Erasmus Governance Design Studio and post-doc researcher. His academic interest is aimed at diverging topics such as: co-design; the role of citizen initiatives in public policy; co-creation and co-production between citizens and governments.

Prof. Dr. Arwin van Buuren is Endowed Professor of Public Administration at Erasmus University Rotterdam. His research interests are on issues of (co-)design for policy and governance, invitational governance and self-organization, collaborative governance and co-creation, policy innovation and institutional change.

Liselotte Hagen is researcher at the Rigo research institute in the Netherlands. 


\section{References}

Agranoff, R., and M. McGuire. 2001. "Big Questions in Public Network Management Research." Journal of Public Administration Research and Theory 11 (3): 295-326. doi:10.1093/oxfordjournals. jpart.a003504.

Agranoff, R., and M. McGuire. 2003. Collaborative Public Management: New Strategies for Local Governments. Washington DC: Georgetown University Press.

Alexander, E. R. 1995. How Organizations Act Together, Interorganizational Coordination in Theory and Practice. Luxembourg: Gordon and Breach Publishers.

Ansell, C., and A. Gash. 2007. "Collaborative Governance in Theory and Practice." Journal of Public Administration Research \& Theory 18 (4): 543-571. doi:10.1093/jopart/mum032.

Armitage, D., F. Berkes, and N. Doubleday. 2010. Adaptive Co-management: Collaboration, Learning, and Multi-level Governance. Vancouver, Canada: UBC Press.

Aryawan, A., M. Oses, I. Buurma, S. Conradi, M. Schmoch, and E. Vogt. 2016. Community Food Gardens in the Netherlands: Present and Future Challenges, Wageningen University. Wageningen: Wageningen University.

Bardach, E. 1998. Getting Agencies to Work Together: The Practice and Theory of Managerial Craftsmanship. Washington, DC: Brookings Institution Press.

Bryson, J. M., B. C. Crosby, and M. Middleton Stone. 2006. "Design and Implementation of Cross-Sector Collaborations: Propositions from the Literature." Public Administration Review 66 (1): 22-55. doi:10.1111/j.1540-6210.2006.00665.x.

Carey, G., and B. Crammond. 2015. "What Works in Joined-Up Government? an Evidence Synthesis." International Journal of Public Administration 38 (13-14): 1020-1029. doi:10.1080/ 01900692.2014 .982292$.

Duşa, A. 2007. "User Manual for the QCA (GUI) Package in R.” Journal of Business Research 60 (5): 576-586. doi:10.1016/j.jbusres.2007.01.002.

Edelenbos, J., I. van Meerkerk, and T. Schenk. 2016. “The Evolution of Community Self-Organization in Interaction with Government Institutions: Cross-Case Insights from Three Countries.” The American Review of Public Administration 48 (1): 52-66. doi:10.1177/0275074016651142.

Emerson, K., and A. K. Gerlak. 2014. "Adaptation in Collaborative Governance Regimes." Environmental Management 54 (4): 768-781. doi:10.1007/s00267-014-0334-7.

Emerson, K., T. Nabatchi, and S. Balogh. 2012. "An Integrative Framework for Collaborative Governance." Journal of Public Administration Research and Theory 22 (1): 1-29. doi:10.1093/ jopart/mur011.

Erickson, J. I., G. A. Hamilton, D. E. Jones, and M. Ditomassi. 2003. "The Value of Collaborative Governance/staff Empowerment." The Journal of Nursing Administration 33 (2): 96-104. doi:10.1097/00005110-200302000-00006.

Fiss, P. C. 2011. "Building Better Casual Theories: A Fuzzy Set Approach to Typologies in Organizational Research." Academy of Management Journal 54 (2): 393-420. doi:10.5465/ amj.2011.60263120.

Frantzeskaki, N. 2019. "Seven Lessons for Planning Nature-based Solutions in Cities." Environmental Science and Policy 93: 101-111. doi:10.1016/j.envsci.2018.12.033.

Gupta, J., C. Termeer, J. Klostermann, S. Meijerink, M. van den Brink, P. Jong, E. Bergsma, and E. Bergsma. 2010. "The Adaptive Capacity Wheel: A Method to Assess the Inherent Characteristics of Institutions to Enable the Adaptive Capacity of Society." Environmental Science and Policy 13 (6): 459-471. doi:10.1016/j.envsci.2010.05.006.

Healey, P. 1998. "Building Institutional Capacity through Collaborative Approaches to Urban Planning." Environment and Planning A 30 (9): 1531-1546. doi:10.1068/a301531.

Marx, A., and A. Dusa. 2011. "Crisp-Set Qualitative Comparative Analysis (Csqca), Contradictions and Consistency Benchmarks for Model Specification.” Methodological Innovations Online 6 (2): 103-148. doi:10.4256/mio.2010.0037.

Meyer, J. W., and B. Rowan. 1977. "Institutionalized Organizations: Formal Structure as Myth and Ceremony.” American Journal of Sociology 83 (2): 340-363. doi:10.1086/226550.

Milward, H. B., and K. G. Provan. 2006. A Manager's Guide to Choosing and Using Collaborative Networks. Vol. 8. DC: IBM Center for the Business of Government Washington.

Newman, J., M. Barnes, H. Sullivan, and A. Knops. 2004. "Public Participation and Collaborative Governance.” Journal of Social Policy 33 (2): 203-223. doi:10.1017/S0047279403007499. 
Osborne, S. P. 2006. “The New Public Governance?” Public Management Review 8 (3): 377-387. doi:10.1080/14719030600853022.

Ostrom, E. 2005. Understanding Institutional Diversity. New Jersey: Princeton University Press.

Pahl-Wostl, C. 2009. "A Conceptual Framework for Analysing Adaptive Capacity and Multi-level Learning Processes in Resource Governance Regimes." Global Environmental Change 19 (3): 354-365. doi:10.1016/j.gloenvcha.2009.06.001.

Provan, K. G., \& Kenis, P. (2008). "Modes of network governance: Structure, management, and effectiveness." Journal of public administration research and theory 18(2): 229-252.

Putnam, R. D. 2000. Bowling Alone. New York: Simon and Schuster.

Raab, M., \& Stuppert, W. (2014). Review of evaluation approaches and methods for interventions related to violence against women and girls (VAWG). Department for International Development.

Ragin, C. C. 1987. The Comparative Method: Moving beyond Qualitative and Quantitative Strategies. Oakleand: Univ of California Press.

Ragin, C. C. 2008a. Redesigning Social Inquiry Fuzzy Sets and beyond Analysis of Causal Complexity versus Analysis of Net Effects. Hoboken: Wiley Online Library.

Ragin, C. C. 2008b. “USER' S GUIDE TO Fuzzy-Set/Qualitative Comparative Analysis.” Accessed 28 March 2019, www.u.arizona.edu/ cragin/fsQCA/download/fsQCAManual.pdf.

Rihoux, B., and B. Lobe. 2009. "The Case for Qualitative Comparative Analysis (QCA): Adding Leverage for Thick Cross-case Comparison." In The Sage Handbook of Case-based Methods, edited by D. Byrne and C. C. Ragin, 222-242. London: Sage Publications.

Rihoux, B., and C. C. Ragin. 2008. Configurational Comparative Methods: Qualitative Comparative Analysis (QCA) and Related Techniques (Vol. 51). Washington, DC: Sage Publication.

Rosol, M. 2010. "Public Participation in post-Fordist Urban Green Space Governance: The Case of Community Gardens in Berlin." International Journal of Urban and Regional Research 34 (3): 548-563. doi:10.1111/j.1468-2427.2010.00968.x.

Scharpf, F. W. 1997. "Introduction: The Problem-solving Capacity of Multi-level Governance." Journal of European Public Policy 4 (4): 520-538. doi:10.1080/135017697344046.

Scharpf, F. W. 2000. "Institutions in Comparative Policy Research." Comparative Political Studies 33 (6-7): 762-790. doi:10.1177/001041400003300604.

Schneider, C. Q., and C. Wagemann. 2010a. "Qualitative Comparative Analysis (QCA) and Fuzzy-Sets: Agenda for a Research Approach and a Data Analysis Technique." Comparative Sociology 9 (3): 376-396. doi:10.1163/156913210X12493538729838.

Schneider, C. Q., and C. Wagemann. 2010b. "Standards of Good Practice in Qualitative Comparative Analysis (QCA) and Fuzzy-Sets." Comparative Sociology 9 (3): 397-418. doi:10.1163/ $156913210 X 12493538729793$.

Schneider, C. Q., and C. Wagemann. 2012. Set-Theoretic Methods for the Social Sciences: A Guide to Qualitative Comparative Analysis (Strategies for Social Inquiry). New York: Cambridge University Press.

Schneider, C. Q., and I. Rohlfing. 2013. "Combining QCA and Process Tracing in Set-Theoretic Multi-Method Research." Sociological Methods and Research 42 (4): 559-597. doi:10.1177/ 0049124113481341.

Sørensen, E., and J. Torfing. 2009. "Making Governance Networks Effective and Democratic through Metagovernance.” Public Administration 87 (2): 234-258. doi:10.1111/j.1467-9299.2009.01753.x.

Sørensen, E., and J. Torfing. 2012. "Collaborative Innovation in the Public Sector." The Innovation Journal 17 (1): 1-14.

Stoker, G. 1998. "Governance as Theory: Five Propositions." International Social Science Journal 50 (155): 17-28. doi:10.1111/1468-2451.00106.

Thomann, E., and S. Wittwer. 2017. Performing Fuzzy- and Crisp Set QCA with R: A User-oriented Beginner's Guide,64. Accessed June 6th 2019. http://www.evathomann.com/links/qca-r-manual

van Meerkerk, I., and J. Edelenbos. 2014. "The Effects of Boundary Spanners on Trust and Performance of Urban Governance Networks: Findings from Survey Research on Urban Development Projects in the Netherlands." Policy Sciences 47 (1): 3-24. doi:10.1007/s11077-0139181-2.

Van Meerkerk, I., R. Kleinhans, and A. Molenveld. 2018. "Exploring the Durability of Community Enterprises: A Qualitative Comparative Analysis." Public Administration 96 (4): 615-667. doi:10.1111/padm.12523. 
Van Slyke, D. M. 2007. "Agents or Stewards: Using Theory to Understand the Government-nonprofit Social Service Contracting Relationship." Journal of Public Administration Research and Theory 17 (2): 157-187. doi:10.1093/jopart/mul012.

Voets, J., K. Verhoest, and A. Molenveld. 2015. "Coordinating for Integrated Youth Care: The Need for Smart Metagovernance.” Public Management Review 17 (7): 981-1001. doi:10.1080/ 14719037.2015.1029347.

\section{Appendix A. Parsimonious solution}

Two configurations leading to durable gardens:

(1) FINANCIAL INDEPENDENCE (cons: 0.78, PRI: 0.70, Raw Coverage: 0.66, Unique coverage: $0.44)$

N = 7: Voedselbos; DaktuinHuisvandeWijk; DeGroeituinen,GillisParadijs,Bikkershof, Voedseltuin,Carnissetuin

(2) non-shared leadership ${ }^{\star}$ STRONG INSTITUTONALIZATION (cons. 0.89, PRI: 0.80, Raw Coverage: 0.30 , Unique coverage: 0.08 )

$\mathrm{N}=2$, Gras van de Buren, Voedselbos

Total solution scores (cons.: 0,80 , PRI: 0.72 , coverage: 0,74 )

One configuration leading to non-durable gardens:

(1) Low institutionalization AND financial dependence (cons.: 0,87, PRI: 0,80, Raw Coverage: 0,47)

$\mathrm{N}=2$ : HalteWestplein; Plukenproeftuin 